\title{
In vitro expression and antiserum production against the movement protein of Citrus leprosis virus C (CiLV-C)
}

\author{
Renata F. Calegario ${ }^{1}$, Mônica T.V. Labate ${ }^{2}$, Luís A. Peroni ${ }^{3}$ Dagmar Ruth Stach-Machado ${ }^{3}$, Maxuel O. \\ Andrade $^{4}$, Juliana Freitas-Astúa ${ }^{5,6}$, Carlos A. Labate ${ }^{2}$, Marcos A. Machado $^{6}$ \& Elliot W. Kitajima ${ }^{1}$
}

${ }^{1}$ Departamento de Fitopatologia e Nematomologia, Escola Superior de Agricultura "Luiz de Queiroz", Universidade de São Paulo, 13418-900, Piracicaba, SP, Brazil; ²Departamento de Genética, Escola Superior de Agricultura "Luiz de Queiroz", Universidade de São Paulo, 13418-900, Piracicaba, SP, Brazil; ${ }^{3}$ Departamento de Imunologia, Universidade de Campinas, 13100-000, Campinas, SP, Brazil; ${ }^{4}$ Departamento de Bioquímica, Instituto de Química, Universidade de São Paulo, 05508900, São Paulo, SP, Brazil; ${ }^{5}$ Embrapa Mandioca e Fruticultura Tropical, 43380-000, Cruz das Almas, BA, Brazil; ${ }^{6}$ Centro APTA Citros Sylvio Moreira, 13490-970, Cordeirópolis, SP, Brazil

Author for correspondence: Renata F. Calegario, email: rfaier@hotmail.com

\begin{abstract}
Citrus leprosis, caused by Citrus leprosis virus $\mathrm{C}$ (CiLV-C), is currently considered the most important viral disease in the Brazilian citrus industry due to the high costs required for the chemical control of its vector, the mite Brevipalpus phoenicis. The pathogen induces a non-systemic infection and the disease is characterized by the appearance of localized lesions on citrus leaves, stems and fruits, premature fruit and leaf drop and dieback of stems. Attempts were made to promote in vitro expression of the putative cell-to-cell movement protein of CiLV-C in Escherichia coli and to produce a specific polyclonal antibody against this protein as a tool to investigate the virus-plantvector relationship. The antibody reacted strongly with the homologous protein expressed in vitro by ELISA, but poorly with the native protein present in leaf lesion extracts from sweet orange caused by CiLV-C. Reactions from old lesions were more intense than those from young lesions. Western blot and in situ immunolocalization assays failed to detect the native protein. These results suggest low expression of the movement protein (MP) in host tissues. Moreover, it is possible that the conformation of the protein expressed in vitro and used to produce the antibody differs from that of the native MP, hindering a full recognition of the latter.
\end{abstract}

Key words: Brevipalpus phoenicis, Cilevirus, Citrus sinensis, polyclonal antibody, serology.

Citrus leprosies, caused by Citrus leprosis virus $C$ (CiLV-C), is considered one of the most important diseases for the citrus industry in the Americas. Sweet orange varieties [Citrus sinensis (L.) Osbeck] are highly susceptible to the virus, and plants may be completely destroyed if left untreated (Müller et al., 2005). In Brazil, around US\$ 100 million are spent annually for the chemical control of its vector, the false spider mite Brevipalpus phoenicis (Geijskes) (Acari: Tenuipalpidae) (Bastianel et al., 2006). The disease symptoms are characterized by chlorotic or necrotic local lesions on the leaves, stems and fruit at the mites' feeding areas. Furthermore, it can lead to heavy losses due to the drop of leaves and fruits and, eventually, the premature death of the trees (Bastianel et al., 2010). CiLV-C, recently classified as the type species of a new genus of plant viruses, Cilevirus (Carstens, 2010), has a bipartite genome composed by two ssRNA molecules of positive polarity (Locali-Fabris et al., 2006; Pascon et al., 2006). RNA 1 (8745 nucleotides - nt) contains two open reading frames (ORFs), which potentially encode 286 and $29 \mathrm{kDa}$ proteins. The $286 \mathrm{kDa}$ protein is a polyprotein putatively involved in virus replication, and the $29 \mathrm{kDa}$ protein is the putative coat protein of CiLV-C. RNA 2 (4986 nt) contains four ORFs which potentially encode, respectively, 15, 61, 32 and $24 \mathrm{kDa}$ proteins. Among these, only the $32 \mathrm{kDa}$ protein, encoded by ORF 3 , has a putative function assigned, apparently being involved in cell-to-cell movement of the virus (Locali-Fabris et al., 2006; Pascon et al., 2006).

Despite the sequencing of the CiLV-C genome, there is still lack of essential information about the leprosis pathosystem such as the infection and replication processes of the virus in the hosts, the precise virus/vector relationship and the reasons for the absence of systemic infection. Thus, the studies involving analyses of the expression of viral proteins in the host cells consist in one of the strategies to better understand the interactions that occur between the virus and its hosts (Hull, 2002). One alternative for the study of virus/host/vector relationship is to follow the expression of viral genes using immunological techniques based on antibodies produced against the different viral proteins. Unfortunately, traditional methods to raise antibodies against viral structural proteins using purified virus preparations have been unsuccessful for CiLV-C due to the low viral titer in the plant tissues and the instability of the particles (Colariccio et al., 2000). A way to overcome such difficulties is to use viral proteins expressed in vitro as 
immunogens (Zerbini et al., 2002). As part of the strategies to advance in studies related with in situ detection of the virus proteins, we attempted to promote the in vitro expression of the ORF 3, the putative viral movement protein (MP) of CiLV-C, and to produce a specific polyclonal antibody. This antibody would serve to detect the MP in infected plants by PTA-ELISA, Western blot and in situ immunolocalization.

MPs are present in the genomes of most plant viruses and are implicated in cell-to-cell movement of the infectious material associated with the plasmodesmata (Wolf et al., 1989; Deom et al., 1990; Haupt et al., 2005; Akamatsu et al., 2007). In the CiLV-C pathosystem, there is a particular interest to follow the MP expression and its fate in the plant cells to understand why the infection is localized and not systemic. It is important to point out that most of the studies related to MPs are concentrated in their function or loss of function through mutations, production of transgenic plants, cellular localization and increasing of the size exclusion limit of the plasmodesmata, and interaction with other proteins in protoplasts cells (Wolf et al., 1989; Deom et al., 1990; Haupt et al., 2005; Akamatsu et al., 2007). Moreover, the peculiarity of MPs as non structural proteins contributes to the scarcity of studies related to antibody production and in vivo detection.

The dsRNA extraction from leaf lesions and cDNA syntheses were performed according to the protocols described by Locali et al. (2003). The full-length sequence of ORF 3 (gb_DQ352194) was amplified using $3 \mu \mathrm{L}$ of cDNA, $2.5 \mu \mathrm{L}$ of $10 \mathrm{x}$ buffer, $0.9 \mu \mathrm{L}$ of $50 \mathrm{mM} \mathrm{MgCl}, 0.5$ $\mu \mathrm{L}$ of $2.5 \mathrm{mM}$ dNTP mix, $0.5 \mu \mathrm{L}$ of each specific primer (10 $\mu \mathrm{M}), 0.2 \mu \mathrm{L}(1.5 \mathrm{U})$ of Taq DNA polymerase (Invitrogen) and sterile Milli-Q water to $25 \mu \mathrm{L}$ final volume. The primers used for the complete $m p$ amplification were: MP forward (5'CAC CAT GGC TCT TTC TAC CAA TAA CAA3'), MP reverse (5'TTA TTC GCT TGT AGAAGT TGA GC3'). The reaction was performed using a PTC 100 (MJ Researcher, Walthan, MA) thermocycler programmed for 30 cycles of denaturation at $94^{\circ} \mathrm{C}$ for $30 \mathrm{~s}$, annealing at $56^{\circ} \mathrm{C}$ for $30 \mathrm{~s}$ and extension at $72^{\circ} \mathrm{C}$ for $40 \mathrm{~s}$. A final 5 minutes extension at $72^{\circ} \mathrm{C}$ was added to the last cycle. PCR products were visualized in a $1 \%$ agarose gel containing $0.5 \mu \mathrm{g}$ ethidium bromide $\mathrm{mL}^{-1}$.

Cloning was performed using the Gateway technology (Invitrogen), following manufacturer's instructions. At first, the MP amplicon was cloned into the entry vector using the pENTR Directional TOPO Cloning kit (Invitrogen), and then transferred to pDEST17 according to the manufacturer's instructions. The clones of pDEST17/mp were confirmed by PCR and sequencing. The pDEST17/mp plasmid was extracted from E. coli DH5 $\alpha$ by the alkaline lysis method (Sambrook et al., 1989) and three E. coli strains, BL21-DE3, BL21-DE3-pLysS and BL21-DE3-RP, were transformed (Sambrook et al., 1989) using $10 \mathrm{ng}$ of plasmid DNA, to select the most efficient strain for in vitro protein expression. The selected strain BL21-pLysS/mp was grown in $500 \mathrm{~mL}$ of $2 \mathrm{xYT}$ medium with $100 \mathrm{mg} / \mathrm{L}$ of ampicillin and chloramphenicol at $37^{\circ} \mathrm{C}$ until O.D. ${ }_{600}$ equal to 0.6. At that moment, it was added 0.2 $\mathrm{mM}$ of IPTG and, after 3 hours, the whole volume was transferred to centrifuge tubes and centrifuged at 5,000 rpm (Beckman F0650 rotor) for 12 min at $4^{\circ} \mathrm{C}$. The supernatants were discarded and the tubes with the bacterial pellets were stored at $-80^{\circ} \mathrm{C}$.

Two tubes containing pellets from BL21-pLysS $/ m p$ cells were resuspended in $8 \mathrm{~mL}$ of lysis buffer (Tris $50 \mathrm{mM}$, EDTA $1 \mathrm{mM}, \beta$-2-mercaptoetanol $14 \mathrm{mM}, 25 \%$ sacarose, $\mathrm{pH}$ 8.5) each and the final volume submitted to physical lysis by "French Pressure Cell Press" (SLM AMINCO, SLM Instruments, Inc). The solution was centrifuged at 15,000 rpm (Beckman F0650 rotor) for $30 \mathrm{~min}$ at $4^{\circ} \mathrm{C}$, and the supernatant (soluble protein fraction) was collected to be analyzed for the presence of the MP protein by SDS-PAGE. The precipitate was resuspended in $20 \mathrm{~mL}$ of solubilization buffer (Urea $6 \mathrm{M}$, Tris $50 \mathrm{mM}$, EDTA $1 \mathrm{mM}, \beta$-2-mercaptoetanol $14 \mathrm{mM}, \mathrm{pH} \mathrm{8.5),} \mathrm{homogenized}$ and incubated for $50 \mathrm{~min}$ under slow agitation at room temperature. After that, the solution was centrifuged at 15,000 rpm (Beckman F650 rotor) for $40 \mathrm{~min}$ at $4^{\circ} \mathrm{C}$ and the supernatant (insoluble protein fraction) collected to be analyzed for the presence of the MP by SDS-PAGE and mass spectrometry in a Q-TOF-Ultima API mass spectrometer (Waters).

For MP purification, the insoluble protein fraction was initially submitted to two consecutive purifications by ion exchange chromatography using, at first, an SQ Sepharose column (GE Healthcare) followed by an SP Sepharose column (GE Healthcare). A third purification by affinity chromatography with immobilized metal was carried out with a HisTrap HP column (GE Healthcare), according to the manufacturer's instructions. The fraction containing the MP was quantified by measuring the absorbance at 280 nm.

The immunization program consisted of six injections. Once a week, $200 \mu \mathrm{g}$ of pure MP were injected in a New Zealand rabbit. The first dose was prepared using a 1:1 ratio (v/v) of MP to complete Freund's adjuvant, and it was injected by subcutaneous form in the dorsum of the rabbit, after collecting the pre-immune bloody. The subsequent doses were injected as described above, but using incomplete Freund's adjuvant.

PTA-ELISA was carried out as described by Mowat \& Dawson (1987) using symptomatic leaf lesions from Pêra sweet oranges at different levels of disease development (Figure 1). Samples were visually separated into three categories: young lesions (YL), intermediary lesions (IL) and old lesions (OL) and were tested in a 1:50 dilution $(\mathrm{w} / \mathrm{v})$ with the MP antibody diluted at 1:1000. Further tests were conducted using OL samples diluted at 1:30, 1:20 and $1: 10(\mathrm{w} / \mathrm{v})$ and the MP antibody diluted at 1:800, 1:400, 1:200 and 1:100 (v/v). Tissues from healthy plants at the same dilutions were used as negative controls. The samples analyzed by Western blot were the same used for PTA-ELISA but, in this case, they were ground in $0.5 \mathrm{M}$ tris- $\mathrm{HCl}$ buffer 
$\mathrm{pH} 6.8$ in a 1:3 ratio $(\mathrm{w} / \mathrm{v})$. The procedure was carried out as described by Barbosa-Mendes (2007) with the antibody diluted at 1:200 (v/v). For in situ immunolocalization assays, fragments of leaf lesions from sweet orange infected with CiLV-C were fixed in a modified Karnovsky solution $(2.5 \%$ glutaraldehyde, $2 \%$ paraformaldehyde in $0.05 \mathrm{M}$, pH 7.2 cacodylate buffer), dehydrated in ethanol and embedded in LR White resin. Ultrathin sections $(70 \mathrm{~nm})$ were mounted on nickel grids and immunolabelled using the protocol of Maunsbach \& Afzelius (1999) with the MP antibody diluted at 1:100 and 1:1000 (v/v). Specimens were examined in a Zeiss EM 900 transmission electron microscope. Healthy sweet orange tissues were used as controls.

The RT-PCR amplified product, herein referred to as $m p$, presented the expected size of $c a .890 \mathrm{bp}$. Several pENTR $\mathrm{D}-\mathrm{TOPO} / \mathrm{mp}$ clones were obtained, some of which revealed to contain the $890 \mathrm{bp}$ fragment by PCR. Sequencing of the vector confirmed that the fragment was cloned in the correct orientation without nucleotide changes. The clone selected presented an $98 \%$ identity with the CiLV-C isolate from Cordeirópolis (DQ352194 for RNA 2). Subsequent cloning of the amplicon into pDEST17 was confirmed by PCR and bacterial growth in the presence of chloramphenicoland. The clone selected for protein expression was verified for the presence of the Shine-Delgarno sequence and the six aligned histidines.

The MP expression levels obtained for the different E. coli BL21 strains tested showed no significant difference. The expressed protein had a molecular mass of $c a .35 \mathrm{kDa}$, close to the value of $32.5 \mathrm{kDa}$ estimated by Locali-Fabris et al. (2006) for the CiLV-C putative movement protein. The difference of $2.5 \mathrm{kDa}$ on the in vitro MP mass is due to the six histidine tag of the recombinant MP. BL21-DE3-pLysS was the selected strain for large scale expression because of its capacity to suppress the basal expression of the $\mathrm{T} 7$ promoter due to the production of $\mathrm{T} 7$ lysozyme, a natural inhibitor of T7 RNA polymerase. The extraction of the expressed protein from E. coli BL21-DE3-pLysS cells demonstrated that the MP was present only in the insoluble fraction, probably as the result of inclusion bodies formation (Martínez-Alonso et al., 2009). Similar cases of insolubility of proteins expressed in E. coli system were reported with the replicases of Tobacco mosaic virus (TMV) and Citrus tristeza virus (CTV) (Hills et al., 1987; Çevik et al., 2008) and with TMV MP (Chen et al., 2000). The formation of inclusion bodies is not correlated with the size of the synthesized polypeptide, the use of a fusion construct, the subunit structure, or the relative hydrophobicity of the recombinant protein. Overproduction by itself can be sufficient to induce the formation of these inclusions (Schumann \& Ferreira, 2004). Attempts to prevent the formation of inclusion bodies by growing bacterial cultures at low temperature $\left(14^{\circ} \mathrm{C}\right)$ were unsuccessful (R.F. Calegario, unpublished data). On the other hand, the use of urea during MP extraction from the insoluble fraction solubilizes the protein but could result in its undesirable denaturation. This process is highly relevant for antibody production due to the possibility of losing the original three-dimensional conformation of the protein, which can lead to a problem in recognition of the native MP in infected plants by the antibody produced. A similar problem occurred in our attempt to in vitro express the helicase domain of CiLV-C RdRp using the same vector system (R.F. Calegario, unpublished data). The sequencing by mass spectrometry of MP purified from the insoluble

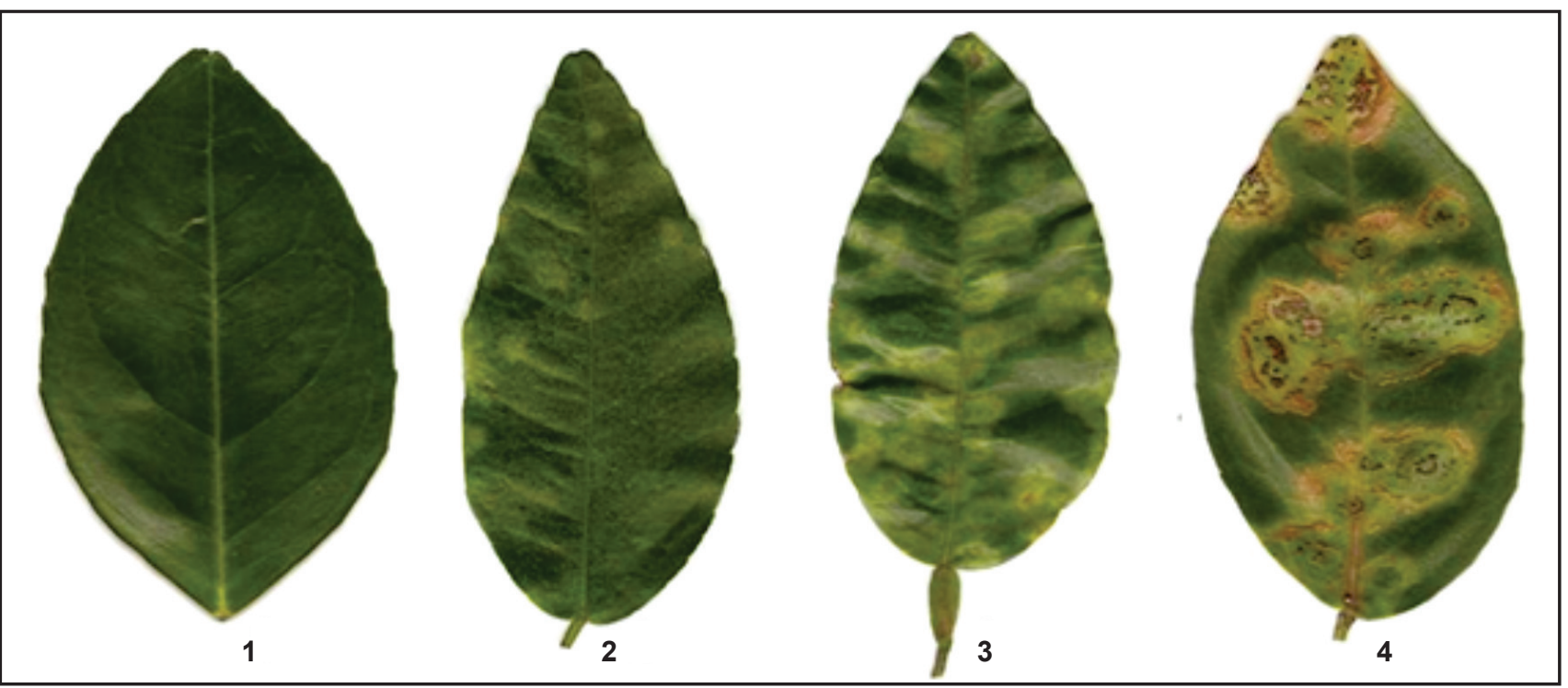

FIGURE 1 - Leaves from Pêra sweet orange infected by CiLV-C at different levels of disease development. 1, Healthy; 2, Young lesions (YL) ; 3, Intermediary lesions (IL); 4, Old lesions (OL). 
fraction indicated the identity with the CiLV-C p32 protein (DQ352194) and thus confirmed the success of the in vitro expression of the putative CiLV-C MP. Expressed MP was purified from the insoluble fraction by three sequential steps, the last of which required a HisTrap HP system and resulted in a highly purified and concentrated protein, with $1.25 \mathrm{mg} / \mathrm{mL}$ in the eluted fraction (Figure 2).

The produced antibody reacted specifically with the injected protein by PTA-ELISA. The same assay, using extracts of symptomatic sweet orange leaves as antigens diluted 1:50 and anti-MP serum diluted 1:1000, also resulted positive. It was noticed that, as a rule, older lesions yielded a stronger reaction compared to younger lesions. No significant reaction was observed in extracts from uninfected, control leaves.

Further assays showed that immunodetection of MP may sometimes be erratic, suggesting that MP concentration is likely to be low in infected tissues. This has already been noticed in the detection of CiLV-C by RT-PCR, when larger

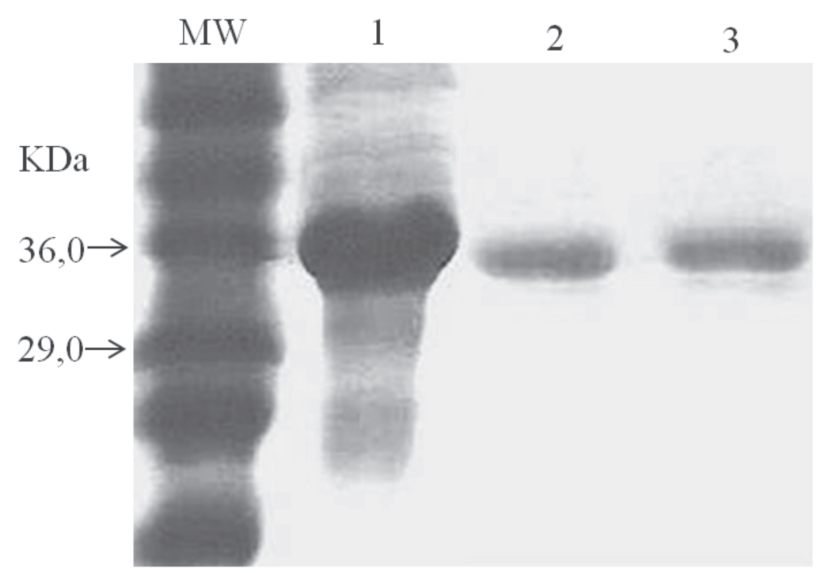

FIGURE 2 - SDS-PAGE of pure movement protein obtained after purification with the HisTrap HP column. M, Broad range molecular weight markers (BioRad); 1, Insoluble protein extract, $5 \mu \mathrm{L}$ (1:3 dilution of insoluble protein to buffer); 1 and 2 , Pure MP in the eluted fraction after purification, $10 \mu \mathrm{L}(2: 1$ dilution of $\mathrm{MP}$ protein to buffer). chlorotic lesions were more appropriate than necrotic lesions (Antonioli-Luizon et al., 2004). CiLV-C detection in the tissues by transmission electron microscopy also revealed that while in younger small lesions most of the cells were infected, in older larger lesions the virus could be detected only in a few parenchymal cells (Gomes et al., 2004).

Different dilutions of the antigen and antibody were tested to find an optimal combination for MP detection, considering a possible diagnostic application. Older CiLV-C lesions from infected Pêra sweet orange were used as antigens, since preliminary data indicated better PTAELISA results for that kind of sample. The results indicate that MP can be detected in mature leaf lesions from CiLVC-infected Pêra sweet orange by PTA-ELISA. The optimal conditions for the diagnosis are 1:10 to $1: 20$ dilution of the leaf extract and 1:100 to 1:200 dilution of the anti-MP serum (Table 1). Because of its limited sensitivity, anti-MP antiserum may not be appropriate for diagnostic purposes. Indeed, the recent development of a highly selective and reactive anti-p29 (the putative capsidal protein) of CiLV-C has allowed the immunodetection of this virus and can be used for disease diagnosis (Locali-Fabris et al., 2008).

Pure expressed MP was efficiently detected by the anti-MP serum in Western blot assays. However, similar tests carried out using extracts from symptomatic sweet orange leaves were unsuccessful. Also, in situ immunolocalization assays failed to detect the native MP. No significant labeling by anti-MP antibody was observed in CiLV-C infected tissues. A possible explanation for these failures is that MP has high hydrophobicity and is associated with membranes of the host cell (Chen et al., 2000). Such circumstances make its solubilization difficult, even after boiling the samples. Another hypothesis is that the expressed protein undergoes a different post-translational folding, resulting in completely different epitopes compared to the native MP protein. Or, alternatively, the expressed protein may be properly folded but suffers alterations during the extraction procedure from the insoluble protein fraction. Finally, the amount of MP present in the tissues may be very low, as suggested by preliminary RT-qPCR studies following the expression of different CiLV-C ORFs during the evolution of the infection, in which expression of ORF 3 goes almost unnoticed (Nicolini-Teixeira et al., 2008).

TABLE 1 - Absorbance values (405 nm) obtained in PTA-ELISA. 1:10, 1:20 or 1:30, Ratio between leaf extracts from old lesions or healthy leaves to carbonate buffer (w/v). Reaction time: 3 hours after substrate addition

\begin{tabular}{|c|c|c|c|c|c|c|}
\hline \multirow{3}{*}{$\begin{array}{l}\text { Anti-MP } \\
\text { antiserum } \\
\text { dilution }\end{array}$} & \multicolumn{6}{|c|}{ Leaf extract dilution } \\
\hline & \multicolumn{2}{|c|}{$1: 10$} & \multicolumn{2}{|c|}{$1: 20$} & \multicolumn{2}{|c|}{$1: 30$} \\
\hline & Control (-) & Infected $(+)$ & Control (-) & Infected $(+)$ & Control (-) & Infected (+) \\
\hline $1: 100$ & - & - & 0.301 & 0.623 & 0.300 & $0 ., 466$ \\
\hline $1: 200$ & 0.230 & 0.500 & 0.200 & 0.420 & 0.198 & 0.310 \\
\hline $1: 400$ & 0.111 & 0.283 & 0.100 & 0.231 & 0.095 & 0.173 \\
\hline $1: 800$ & 0.068 & 0.176 & 0.07 & 0.141 & - & - \\
\hline
\end{tabular}


As a conclusion, the fact that CiLV-C does not infect its hosts systemically can be related with the involvement of inhibition mechanisms in the viral passage to the phloem, not being possible to discard some difficulty in its replication or in its cell-to-cell movement to the vascular region. There is, in addition, the hypothesis of a possible gene silencing mechanism taking place, what would hinder the detection of the MP transcripts. These results demonstrate the complexity of genetics and biochemical mechanisms involved in the citrus leprosis pathosystem, but open the possibility for further steps towards the development of other interaction studies which can use the purified MP as a tool.

\section{ACKNOWLEDGEMENTS}

This publication represents part of the doctorate thesis of the first author who wishes to acknowledge Fundação de Apoio à Pesquisa do Estado de São Paulo - FAPESP for the scholarship (04/11799-0). This work receive financial support from Fundação de Apoio à Pesquisa do Estado de São Paulo - FAPESP (2008/52691-9).

\section{REFERENCES}

Akamatsu N, Takeda A, Kishimoto M, Kaido M, Okuno T, Mise K (2007) Phosphorilation and interaction of movement protein and coat proteins of Brome mosaic virus in infected barley protoplasts. Archives of Virology 152:2087-2093.

Antonioli-Luizon R, Freitas-Astúa J, Locali EC, Rodrigues V, Astúa-Monge G, Kitajima EW, Machado MA (2004) Viabilidade da detecção do vírus da leprose dos citros, tipo citoplasmático, em amostras foliares de citros armazenadas. Laranja 25:357-366.

Barbosa-Mendes JM (2007) Transformação genética de laranjadoce (Citrus sinensis L. Osbeck) com o gene hrpN (harpina) e avaliação de resistência ao cancro cítrico (Xanthomonas axonopodis pv. citri). PhD Thesis. Escola Superior de Agricultura "Luiz de Queiroz". Piracicaba SP.

Bastianel M, Freitas-Astúa J, Kitajima EW. Machado, MA (2006) The citrus leprosis pathosystem. Summa Phytopathologica 32:211220.

Bastianel M, Novelli V, Kubo K, Kitajima EW, Bassanezi R, Machado MA, Freitas-Astúa J (2010) Citrus leprosis: centennial of an unusual mite-virus pathosystem. Plant Disease 94:284-292.

Carstens EB (2010) Ratification vote on taxonomic proposals to the International Committee on Taxonomy of Viruses, 2009. Archives of Virology 155:133-146.

Çevik B, Lee RF, Niblett CL (2008) In vivo and in vitro expression analysis of RNA-dependent RNA polymerase of Citrus tristeza virus. Archives of Virology 153:315-321.

Chen MH, Sheng GH, Handa AK, Citovsky V (2000) Interaction between the tobacco mosaic virus movement protein and host cell pectin methylesterases is required for viral cell-to-cell movement. EMBO Journal 19:913-920.

Colariccio A, Lovisiolo O, Boccardo G, Chagas C.M, D'Aquilio M, Rossetti V (2000) Preliminary purification and double stranded RNA analysis of citrus leprosis virus. Conference of the International Organization of Citrus Virologists 14:159-163.

Deom CM, Schubert KR, Wolf S, Holt CA, Lucas WJ, Beachy RN (1990) Molecular characterization and biological function of the movement protein of Tobacco mosaic virus in transgenic plants. Proceedings of the National Academy of Sciences, USA 81:32843288.

Gomes RT, Appezzato-Da-Glória B, Salaroli RB, Kitajima EW (2004) Distribution of CiLV-C in the citrus leaf lesions. Anais, XII Congresso Brasileiro de Biologia Celular, Campinas SP. (Abstract)

Haupt S, Cowan GH, Ziegler A, Roberts AG, Oparka KJ, Torrance L (2005) Two plant-viral movement proteins traffic in the endocytic recycling pathway. Plant Cell 17:164-181.

Hills GJ, Plaskitt, KA, Young ND, Dunigan DD, Watts JW, Wilson TMA, Zaitlin M (1987) Immunogold localization of the intracellular sites of structural and nonstructural Tobacco mosaic virus proteins. Virology 161:488-496.

Hull R (2002) Matthew's Plant Virology. $4^{\text {th }}$ Ed. London UK. Academic Press.

Locali EC, Freitas-Astúa J, Souza AA, Takita MA, Astúa-Monge G, Antonioli R, Kitajima EW, Machado MA (2003) Development of molecular tool for the diagnosis of leprosis, a major threat to citrus production in the Americas. Plant Disease 87:1317-1321.

Locali-Fabris EC, Freitas-Astúa J, Souza AA, Takita MA, AstúaMonge G, Antonioli R, Rodrigues V, Targon MLP, Machado MA (2006) Complete nucleotide sequence, genomic organization and phylogenetic analysis of Citrus leprosis virus cytoplasmic type. Journal of General Virology 87:2721-2729.

Locali-Fabris EC, Stach-Machado DR, Caserta R, Freitas-Astúa J, Calegario R.F, Salaroli RB, Kitajima EW, Machado MA (2008) In vitro expression and production of antiserum to the capsid protein (P29) of Citrus leprosis virus C. In: Anais, Congresso Brasileiro de Fitopatologia. Belo Horizonte MG. CD ROM.

Martínez-Alonso M, Gonzáles-Montabán N, García-Fruítos E, Villaverde A (2009). Learning about protein solubility from bacterial inclusion bodies. Microbial Cell Factories 8:4-6.

Maunsbach AB, Afzelius B (1999) Biomedical electron microscopy: Illustrated methods and interpretations. $4^{\text {th }}$ Ed. San Diego USA. Academic Press.

Mowat WP, Dawson S (1987) Detection of plant viruses by ELISA using crude sap extracts and unfractionated antisera. Journal of Virological Methods 15:233-247.

Müller GW, Targon MLPN, Carvalho AS, Souza AA, Rodrigues JCV (2005) Doenças de citros causadas por vírus e viróides. In: Mattos Júnior De Negri JD, Pio RM, Pompeu Júnior J Citros. $1^{\text {st }}$ Ed. Campinas SP. Instituto Agronômico e Fundag. pp. 567-604.

Nicolini-Teixeira F (2008) Leprose dos citros: Interações planta $\mathrm{x}$ vírus $\mathrm{x}$ vetor. PhD Thesis. Universidade de Passo Fundo. Passo Fundo RS.

Pascon RC, Kitajima JP, Breton MC, Assumpção L, Greggio C, Zanca AS, Okura VK, Alegria MC, Camargo ME, Silva GGC, Cardozo CC, Vallim MA, Franco SF, Silva VH, Jordão Júnior H, Oliveira F, Giachetto PF, Ferrari F, Aguilar-Vildoso CI, Francischini, FJB, Silva JMF, Arruda P, Ferro JÁ, Reinach F, Silva ACR (2006) The complete nucleotide sequence and genomic organization of Citrus leprosis associated virus, cytoplasmatic 
type (CiLV-C). Virus Genes 32:289-298.

Sambrook J, Fitsch E F, Maniatis TM (1989) Molecular cloning: A laboratory manual. $2^{\text {nd }}$ Ed. New York. CSH Laboratory Press, Cold Spring Harbor.

Schumann W, Ferreira LC (2004) Production of recombinant proteins in Escherichia coli. Genetics and Molecular Biology 27:442-453.
Wolf S, Deom CM, Beachy RN, Lucas WJ (1989) Movement protein of Tobacco mosaic virus modifies plasmodesmatal size exclusion limit. Science 246:377-379.

Zerbini FM, Carvalho MG, Zambolim EM (2002) Introdução à virologia vegetal. Cadernos Didáticos 87. Viçosa MG. Universidade Federal de Viçosa.

TPP 375 - Received 9 August 2011 - Accepted 18 March 2012 Section Editor: F. Murilo Zerbini 